\title{
Between the Atlantic West and the Newest Chinese East: Preliminary Remarks About Central-Eastern European Legal Orders and Their Protection of Civil Liberties and Religious Freedom
}

\author{
Domenico Bilotti \\ Magna Graecia University, Catanzaro, Italy
}

\begin{abstract}
The end of Communism in Europe did not mean the end of history. It has just determined the global reduction of worldwide legal systems into a liberal Western model faced by a theocratic organization of power in Middle East or by an aggressive large scale economic competition guided by the Chinese government and its leading Communist Party. Taking a look back at the European Central-Eastern countries, we will easily find a dynamic evolution full of internal contradictions but able anyhow to affirm a sort of revaluation of mixed models, accepting the main financial structures in economic decisions, while preserving a peculiar constitutional belonging in a conceptual survival of their historical, political, and religious roots. It is still unwritten if those movements, doctrines, and paradigms of rules will be enough relevant to represent a solid hypothesis of constitutionalism because there is the risk that Central Europe could reveal a substantial normative and political tightrope incorporating religious elements and renewed economic and symbolic dependence. It is equally clear that those systems have a still not univocal profile that seems paradoxically to be the reason of their permanent interest for legal scholars.
\end{abstract}

Keywords: European Public Law, religious freedom, European Union, democracy

\section{An Introduction: A Bearing Between (and Against) Dominant and Hegemonic States. Could Be the Road to Complexity Even the Road to Freedom?}

It should be clarified that a scientific research unavoidably starts from a selective point of view, with a peculiar methodology, too. The individuation of a precise focus could express the specific intention of the scholar, but he shall demonstrate that his epistemological issues are not just an individual choice: By showing the relevance of his selection, the object of the scientific research can get a universal sense or, at least, a general interest for the academic community (Motilla, 2009).

The attempt to retrace constitutional disciplines and religious conflicts in Central Europe, regarded as the main purpose of this essay, is inevitably the result of a personal experience of studies, lectures, and congresses conducted in those countries. In a deeper sense of reconstructing an absolutely original and various legal framework, and trying to reach an higher level of comprehension of the connected historical roots in local

Domenico Bilotti, Ph.D., professor on contract of “Law and Religion” and “History of Religions”, Department of Jurisprudence, Economics and Sociology, Magna Graecia University, Catanzaro, Italy. 
religious and civil conflicts, to figure out the evolution ongoing in normally neglected or not enough considered European countries is a relevant suggestion for comparative law's scholars. It may allow isolating a post communist paradigm of studies that represents an ideal geographic area between the typical liberal scenery of North America mainly influencing the Western part of the planet and the increasingly uprising Asian economies, reaching hegemonies in the Eastern and Far-Eastern region of the world.

During socialist governments' years, our basic attention was undoubtedly divided into two battling role models: the Atlantic one, based on a democratic constitutional rule of law continuously faced by sometimes aggressive social inequalities in a free market frame (Smith, 1985), and the Communist one, vigorously subjected to the legal, military, and economic rules of the Soviet Union (Luchterhandt, 2005).

This simple outline is nowadays unanimously considered as almost completely faded in its 1970s and 1980s configuration.

This kind of established "bipolar order" has changed at least three times in recent political and international history. First of all, the European community, turned into an unclear form of regional union, tried to become a third leading actor in the world, but that design is usually represented as a failed opportunity, considering the still not stopped decline in social services and internal economies, while new civil stances (migrations, Muslim communities, and the external legal representation of the decisional main issues themselves) surfaced in a quick and somehow dramatic way (Macrì, 2017). On the other hand, Southern American countries have made a wide transformation, creating the idea of being ready to enlarge their worldwide political roles, but even this changing mood has demonstrated its own limits, especially in protecting indigenous communities, in fighting a large and substantially unbeaten level of public corruption and in regulating the fast paradigm shift from a mainly Catholic cultural and religious basement to a Christian reformed radically right wing undirected supremacy in building up the accepted common image of the society.

The last turning point, for too long not enough studied and for too long silently rising, probably consists in the remarkable Chinese impact on markets and large scale factories' production. A Chinese financial strategy could not in an uncorrected way be summarized in buying Western public debts while gaining an important activity in relating to the African countries: A perfect, unquestionable, relevance still depending, anyway, on a low profile internal effort to recognize social rights and environmental stances.

This complex scenery, involving normative regulations, social structures, and international alliances, necessarily recalls the confrontation with mixed legal theoretical and institutional orders trying to pinpoint different approaches, in relating to Western economies and the connected legal protection of civil liberties and in comparing that kind of situation to the ongoing evolution of the Far-Eastern constitutional systems. Central-Eastern Europe concentrates this comparative and methodological demand opening a whole overview of new tendencies, apparently surpassed questions concerning local identities, multinational tutelages, and complicated political balancing acts.

This essay is therefore conceived to reach a double objective: to claim the importance of a sincere and deep look at the current situation in those countries and to prove how their systems cannot be lessened into a monolithic and static conceptual classification, conversely enforcing the hermeneutic virtues of legal pluralism (De Oto, 2012). 


\section{Presenting a Handbook of Case Studies: Duality, Liberal Constitutionalism, Secularism and (Christian) “Orthodox” Revival}

A tangible dualism is still active in the geopolitical figure of this European region: We must consider States already maintaining an inner link to the strength of the Russian Federation-that could even seem the second part of the precedent soviet influence, changed in a new net of relationships between parties, lobbies, and other social groups - and States proudly working in the opposite direction. In this second branch of countries, keeping a connection between law and politics, not always precise from a scientific point of view but usually enough explanatory, we should mention the peculiar record in the area of Slovakia, Slovenia, Latvia, Lithuania, and Estonia. These States could be properly considered the Eastern outpost of the European integration, even discussing the international and ecclesiastical law elements of the particular cases (Doe, 2011): They are members of the European Union, they adopted the common Euro currency; they are part of the NATO alliance (generally, the first international conventional multilateral legal step in the transition from the ancient Russian socialist influence to the acceptation of a liberal-democratic organization of power); they respect and observe the Schengen area regulation-fixed by the notorious Schengen Agreement in 1985.

Even more than considering the comprehensive preliminary and figurative map of international relationships, a legal scholar will gather the specificity of Central and Eastern European States by analyzing their constitutional hierarchic choices and their customary traditions in religious affairs and beliefs. In the Baltic States, for instance, in secular societies not hostile to social frequent phenomena as atheism, indifference, and agnosticism, there are some new pagan movements with a small but entrenched favor, especially in the backcountry (O’Connor, 2006). Czech Republic is the most secular State in Europe, if we use as a parameter the percentage of people declaring themselves not belonging to any religious group or affiliation, but the domestic calendar of national festivities is full of religious references, apart from the anniversaries celebrating the Velvet Revolution and the gradual and finally peaceful separation from the Communist hegemony and regime (Czech people remember saints like Wenceslaus, reform, or at least considered progressive theologians as Jan Hus, Cyrillus, Methodius, and Commenius). The Constitution is a well-balanced set of administrative rules and principles-a long treatise from Article 15 to Article 113-with a first ideal section based on recognizing the rule of law. In regards to that point, it could be useful to remind Article 6: an interesting and concise exemplification of the majority rule and the consequent application ${ }^{1}$.

The socialist legal model, affecting the area for many decades but in various directions, gave those national Constitutions a prevalently atheistic statehood. This institutional mechanism did not properly work out (Read, 1979). Formally considering, the legal ruling of the atheistic statehood means that the indifference and the impartiality for religious affairs become a repressive kind of formal equality: The identical treatment of every religion consists in an open suppression or in a partially hidden oppression. It cannot stand for long in countries, regions, and cultures with a popular conception of faith usually conceived by the people as a contextual spiritual and pragmatic basement of everyday guidelines. It was even more difficult in the socialist Yugoslavia, where the fragmentation of popular faiths was strong (an autochthonous Muslim majority in Bosnia, a strongly perceived Orthodox collective faith in Serbia, a subtler Christian influence in Croatia, with

\footnotetext{
1 "Political decisions shall derive from the will of the majority expressed through free voting. Minorities shall be protected by the majority in decision making”. Please consider that Article 4 reminds the idea of the legal protection of those rights, not only considering the relationship between majority and minorities ("The fundamental rights and freedoms enjoy the protection of the judiciary”).
} 
Protestant and Roman Catholic communities). It determined the well-known and mournful conflict of the Nineties, when religious and ethnic elements were used to justify and to perpetrate the greatest genocide in recent years Europe, against Bosnian Muslims in Srebrenica (Sells, 1998).

An atheistic approach to religious phenomena is quite represented even in Chinese laws and that heritage could be considered an effect of the Soviet influence, when Communist parties gained the power even in Far-Eastern Asia. The constitutional regulation in China seems more interesting, because Article 36 defends a typically individual concept of religious freedom ${ }^{2}$, however, complaining a substantial lack of legal protection for associated religious groups and churches, they need to be recognized by the government in a central administrative organization destined to give patriotic State religious institutions an evidently more favorable treatment (Jianmin, 2019). The protection accorded to the public system of instruction could specifically represent the permanent influence of a Confucianist mentality, in order to keep safe the common legal tradition of deference, loyalty, and obedience, but this point should integrate a deeper analysis to be made in a future reflection (Zhang, 2017; Kim, 2016).

It was undisputable anyhow that the end of Communism, even as a constitutional codified point of view in the regulation of religions, has produced in Europe different effects combined by one, big, point in common: the reemergence of praxes, customs, and beliefs expelled by the so called State public sphere. Facing the opposite side of the Czech Republic secular religious policy, even in refusing any idea of national official agreement with the Roman Catholic Church, otherwise well interested in stipulating conventions with States and other administrative local authorities, we will check the case studies of Hungary, Bulgaria, and Romania.

Hungarian government and Presidency seemed in the last decade an afflictive stronghold of a Christian conception in public life and regulations, even concerning the discipline of civil liberties. It is not uncorrected to underline a sort of sharp pain in governing the new bioethical questions about life and death and a more incisive control in the public field of generally accepted liberal freedoms (speech, thought, association, public demonstrations, and strikes), but this intensive modification of the executive branch is not unpopular in Hungary (Ellian \& Rijpkema, 2018) and, even if important constitutional adjustments were written in a purely restrictive sense, the basic norms about religions-the core law of religious freedom in the Hungarian legal system—stand almost all in the same formal codification (starting with the Constitution, and the Article $60^{3}$, especially $\S \S \mathrm{I}-\mathrm{III})$.

It could seem strange or unpredictable, but a similar perspective still guides the Romanian Constitution; the statehood and the citizenship may appear less secular than the Hungarian ones-if we use as a parameter the percentage of baptized people or the frequency in celebrating religious rites. The main collective faith is not the Roman Catholic Church, but the Orthodox national one. The public dispositions in Romanian laws are a well-built example of adaptation of liberal principles to previously not typically liberal Western contexts (the

\footnotetext{
2 “Citizens of the People's Republic of China enjoy freedom of religious belief. No State organ, public organization or individual may compel citizens to believe in, or not to believe in, any religion; nor may they discriminate citizens who believe in, or do not believe in, any religion. The State protects normal religious activities. No one may make use of religion to engage in activities that disrupt public order, impair the health of citizens or interfere with the educational system of the State. Religious bodies and religious affairs are not subject to any foreign domination”.

3 "In the Republic of Hungary everyone has the right to freedom of thought, freedom of conscience and freedom of religion. This right shall include the free choice or acceptance of a religion or belief, and the freedom to publicly or privately express or decline to express, exercise and teach such religions and beliefs by way of religions actions, rites or in any other way, either individually or in a group. The church and the State shall operate in separation in the Republic of Hungary”.
} 
main case is probably Article 6 of the Constitution ${ }^{4}$, properly entitled "Right to Identity").

Romania and Bulgaria represent significant episodes of the not numerous States, in the European Union, to have in their own demographic traditional composition an important Islamic national autochthonous community—-particularly moving from the groups around the Black Sea, but substantially recalling a wide part of the Slavic Sunni Islam (Wink, 2002). Making this short overview even richer and productively opener, Bulgarian Constitution has, in a legal system to date not so hostile against the eventuality of a collective diversity and the possibility of permanent organized minorities, at least since the establishment of the rule of law in it, an almost strictly confessional norm, curiously much respected also by the secular part of the public opinion: Article 13 is about the role of the Church and the subsequent institutional qualification ${ }^{5}$. The constitutional reference does not regard the internal statue of the Church, but it is about the previous religious-theological inherence of that Church.

\section{A Temporary Conclusion: An Unexplored Bridge Between the West and the East}

This constitutional overview of the so called post-Communist Europe could obviously sound not completely satisfying and some reasons of that lack of satisfaction were hopefully explained in their own genesis, first of all the objective impossibility of converting this complex scenario to easily readable and invariable legal regulations. Those countries have experienced different strategies to face the transitional age that they were living even a decade before that it was unanimously declared by scholars into the academic drafting. It just seems a contradiction, because the post-Communist European normative orders are at the same time the most exposed to social conflicts based on religious identities and radical political proposals and the most reliable in managing the uncertain and problematic periods. They frequently adapt their legislation, not occasionally changing their constitutional norms, often and spontaneously needing a dynamic idea of accommodation, which is more similar to an intercultural juridical point of view than to a sort of evolving idea of overlapping consensus's legal philosophical conceptions.

It is not meant to offer a false irenic and conciliatory vision of struggles, conflicts, and specifically jurisprudential controversies rising in Central-Eastern Europe with a probably unpredicted frequency. These remarks have more modestly underlined the undervalued unexpressed potentiality of those countries in showing enormous series of interesting factors in recomposing the idea of sovereignty escaping from the comfortable categories intended to simplify the legal comparison by merely adopting dualistic schemes soon deformed by the complexity of the juridical culture (secularism versus fundamentalism, Islamism versus Western liberal democracy, free market world trade system versus Communism, protection of the fundamental human rights versus their repudiation, etcetera). In the abused model of a competition engaging the West and the East, we continuously seem to miss the middle, the in-between: always the most interesting part.

\section{References}

De Oto, A. (2012). Diritto e religione nell'Europa di mezzo: La Repubblica Ceca. Bologna: Bononia University Press. Doe, N. (2011). Law and religion in Europe. A comparative introduction. Oxford-New York: Oxford University Press.

\footnotetext{
4 "The State recognizes and guarantees the rights of persons belonging to national minorities to the preservation, development and expression of their ethnic, cultural, linguistic and religious identity. The protection measures taken by the Romanian State for the preservation, development and expression of identity of the persons belonging to national minorities shall conform to the principles of equality and non-discrimination in relation to the other Romanian citizens”.

5 “Eastern Orthodox Christianity shall be considered the traditional religion in the Republic of Bulgaria” (§ 3).
} 
Ellian, A., \& Rijpkema, B. (2018). Introduction. In A. Ellian and B. Rijpkema (Eds.), Militant democracy—political science, law and philosophy (pp. 1-21). Leiden: Springer Nature.

Jianmin, Z. (2019). Religion and law in China. Deventer: Wolters Kluwer Netherlands.

Kim, S. (2016). Public reason Confucianism. Democratic perfezionism and constitutionalism in East Asia. Cambridge, New York: Cambridge University Press.

Luchterhardt, O. (2005). The council for religious affairs. In S. Ramet (Ed.), Religious policy in the Soviet Union (p. 74). Cambridge, New York: Cambridge University Press.

Macrì, G. (2017). L'Europa fra le corti. Diritti fondamentali e questione islamica. Soveria Mannelli: Rubbettino.

Motilla, A. (2009). La ricezione del diritto ecclesiastico in Spagna. In S. Bordonali (Ed.), Il contributo di Francesco Scaduto alla scienza giuridica (pp. 52-54). Milano: Giuffré.

O’Connor, K. (2006). Culture and customs of the Baltic States. Westport, London: Greenwood Press.

Read, C. (1979). Religion, revolution \& the Russian intelligentsia. London, Basingstoke: MacMillan.

Sells, M. A. (1998). The bridge betrayed: Religion and genocide in Bosnia. Berkeley, London, University of California Press.

Smith, R. M. (1985). Liberalism and American constitutional law. Cambridge, London: Harvard University Press.

Wink, A. (2002). Al-Hind: the making of the Indo-Islamic world. Boston, Leiden: Brill Academic Publishers.

Zhang, T. (2017). The laws and economics of Confucianism: Kinship and property in pre-industrial China and England. Cambridge, New York: Cambridge University Press. 